\title{
On Transnational Bureaucrats and Rulemaking
}

\author{
Employed by the intermediaries of the main European powers and \\ having consecrated their works, according to their forces, in achiev- \\ ing a work of European interest, the employees of the Commission \\ believe that they could expect from the community ofpowers some- \\ thing that none of them would refuse to their former servants. \\ Memorandum of the Commission's employees, 1868
}

On 2 October 1861, Colonel Fedor von Drygalski, newly appointed Inspector General of Navigation by the European Commission of the Danube, took an oath 'to conscientiously and with fidelity fulfil' his responsibilities and 'to devote loyally all my efforts to the accomplishment of the duties of my office.' ${ }^{1}$ Drygalski was one of the first employees to pledge allegiance to an international organisation, which wanted its officials to defend more than their own nation's interests.

Drygalski's career qualified him for such an international office. A Prussian Pole by birth, he served as an officer in the Prussian army, which he left due to pecuniary difficulties. He went to India and earned a living surveying, and later entered the Austrian army when it needed troops to crush the Hungarian revolution of 1848-1849. He then moved to Istanbul and was employed as an instructor in the local military school, from where he joined Ömer Fevzi Pasha as his secretary when the latter was appointed governor of the Danube Delta region and Ottoman delegate to the Commission. Following salary payment problems by the Ottoman authorities, Drygalski happily accepted the position of Inspector General which fitted well with his profile at a time when the Ottoman Empire and other member states were debating the

1 National Archives of Romania, Galați Branch, Protocols of the European Commission of the Danube (hereafter PECD), Protocol 138, appendix 2, 2 October 1861. 
criteria for appointing officials in executive positions within the Commission's bureaucracy.

As a 'European' in Ottoman service, Drygalski was a good compromise. Two years after his appointment, John Stokes, the British commissioner, conceded that he had many merits 'in introducing order on the Lower Danube', though Stokes also criticised his philo-Austrian sentiments. But at the same time, Drygalski possessed most of the qualities needed for his office: 'bodily and mental activity', knowledge of several languages, legal literacy, 'an impartial strictness in enforcing the regulations confided to his superintendence and a scrupulous accuracy in not overstepping the limits laid down for him'. Drygalski was, however, an ambitious man, and commissioners needed to keep a firm hand on him. ${ }^{2}$ Despite his fiercely independent character, the Inspector had to accept working under a pseudo-nominal Ottoman sovereignty. ${ }^{3} \mathrm{He}$ was, beyond all appearances, a suitable occupant for this historic position in the early days of the International Civil Service (ICS).

The Commission owed a great deal of its success to the organisation and efficiency of its staff. Its complex bureaucratic apparatus did not result from any arrangement between member states, but was nourished by the increasing needs of navigation, as sensed by the seven (rising to eight in 1878) commissioners and by the organisation's bureaucratic leadership. This drive towards bureaucratisation was significantly aided by the Commission's political and financial autonomy, which allowed the organ to follow an independent staff recruitment policy. In fact, the independence of the Commission's employees was an important factor in marking the beginnings of the ICS. The ICS consists of the people who work for an IO on either a temporary or permanent basis and who, during their employment, are expected, regardless of their national origin, to place the interests of the organisation employing them above all else. ${ }^{4}$

In connection with such discussions about dual loyalties and the importance of norms and rules, this chapter aims to detail, along the institutional layer of analysis, the inner structure of the Commission, one of the early examples of transnational bureaucracies. This invokes the theoretical contributions

2 National Archives of the United Kingdom (TNA), Public Record Office, Foreign Office, FO 78/3220, unnumbered (hereafter unn.) (John Stokes to Earl Russell, Galați, 11 January 1864).

3 Wilhelm Brennecke, Die Länder an der unteren Donau und Konstantinopel:Reise-Erinnerungen aus dem Herbst 1868 (Hannover 1870), 77-81.

4 L.C. Green, 'The Status of the International Civil Service,' Current Legal Problems 7.1 (1954): 192. A newer article without reference to the Commission in Dobromir Mihajlov, "The Origin and the Early Development of International Civil Service,' Miskolc Journal of International Law 1.2 (2004): 79-87. 
of Michael N. Barnett and Martha Finnemore on the relationship between bureaucracy and rulemaking. ${ }^{5}$ The chapter further analyses the context in which the Commission's departments were created, as well as their work in regulating shipping along the Maritime Danube. For Stephen D. Krasner, regimes are 'principles, norms, rules and decision-making procedures', and this chapter claims that a security regime came into being with the creation of a coherent corpus of rules and its subsequent application. ${ }^{6}$ James C. Scott's view on the modern bureaucratic state's objective of imposing legibility and simplification is also relevant here, ${ }^{7}$ especially in proving that the Commission acted as a 'state' whose drive for standardising shipping practices was part of its logics of stability and security over its liquid' jurisdiction. As relevant is the 'technocratic internationalism' framework and the analysis of how transnational experts regarded rulemaking as a cornerstone of a new order. ${ }^{8}$

In 1889 a total of 198 people worked for the Commission, increasing to 359 by 1930. They represented eleven states in 1889 and fourteen nationalities in 1931. Employees were part of seven departments (services) in which the Commission structured its activities and were organised into four categories of staff. In 1931, the organisation hired other 746 workers on a temporary basis, so more than 1,100 people were paid by this transnational organ in the interwar period. ${ }^{9}$

From the beginnings of the organisation, commissioners felt the need to have a bureaucratic structure to support them in fulfilling the task which the Commission had received from Europe's Concert of Powers. By December 1856, they had already decided to establish a Secretariat and a Technical Department. The delegates from France, Prussia and Austria were to invite applicants for the Secretariat, while those from Britain and Prussia were to recruit suitable staff for the Technical Department. ${ }^{10}$ Given the short initial term of the Commission (two years) and the harsh living conditions in the Danube Delta,

$5 \quad$ Michael N. Barnett and Martha Finnemore, 'The Politics, Power, and Pathologies of International Organizations,' International Organization 53.4 (1999): 699-732; eidem, Rules for the World: International Organizations in Global Politics (Ithaca 2004).

6 Stephen D. Krasner, 'Structural Causes and Regime Consequences: Regimes as Intervening Variables,' in: idem (ed.), International Regimes (Ithaca and London 1983), 2.

7 James C. Scott, Seeing Like a State: How Certain Schemes to Improve the Human Condition Have Failed (New Haven and London 1998).

8 Wolfram Kaiser and Johan W. Schot, Writing the Rules for Europe: Experts, Cartels and International Organizations (Basingstoke 2014), 6-8.

9 TNA, Public Record Office, FO 881 (Foreign Office: Confidential Print), File 5874, Danube Commission. Questions Raised by the Ottoman and Italian Delegates. December 1888 to June 1889, f. 31; La Commission Européenne du Danube et son œuvre de 1856 à 1931 (Paris 1931), 109. PECD, Protocol 6, 2 December 1856. 
qualified human personnel had to be well paid to accept the available positions. By July 1857, the Commission had 32 employees in its two departments: a Frenchman, Edmond Mohler, oversaw the Central Office (Bureau Central) as secretary general, working together with fifteen other secretaries, copyists, translators and accountants of various origins. The Technical Department numbered sixteen positions, occupied by engineers, surveyors, hydrographers and drafters, and was run by British engineer-in-chief Charles Augustus Hartley. ${ }^{11}$

The Commission's Central Office in Galați remained the organisation's main bureaucratic department. Its size varied depending on need. By 1862, it had nine employees. Mohler was still its secretary general, and a German, E. de Wolf, acted as accounting secretary. There were two other secretaries, an archivist, two printers, two clerks and a maid. In 1872, the Internal Administration, as the Central Office was rebranded, had five employees: a secretary general, an accounting secretary, an archivist, a clerk and a maid. A decade later, its staff consisted, again, of ten employees. ${ }^{12}$

With institutional consolidation, clearer procedures regulated the activities of the Commission's complex staff. Employees were part of seven departments called 'services', each led by a head of service. Decisions relating to recruitment of staff, employment and promotion were taken by commissioners during their plenary sessions, while daily business was directed by the Executive Committee, in which commissioners rotated monthly according to a preliminary agreed schedule. The Executive Committee was made up of at least two commissioners, one tasked with administrative matters (Administration Delegate) and the other with financial ones (Finance Delegate). Commissioners periodically inspected the activity of subordinated staff and reported on the various problems they encountered.

Sometimes, such inspections led to serious arguments within the Commission. On 12 October 1888, Maxime Effendi, a newly appointed Ottoman commissioner, started on a tour of inspection. In the report he submitted to his colleagues, Maxime touched upon several dysfunctionalities, from the too-simple furniture in the organisation's office at Tulcea to the procedures involving recording goods in ledgers in the Commission's storehouses and workshops at Sulina. He interviewed workers and checked their timesheets, enquired into their salaries, counted money, and inspected ledgers in the Cash Office. His inexperience with the Commission's practices fuelled a clash

\footnotetext{
11 Ibid., Protocol 43, 11 July 1857.

12 Ibid., Protocol 151, appendix no. 2, Budget for 1863, 13 November 1862; Protocol 278, appendix no. 1, Budget for 1873, 11 November 1872; Protocol 399, appendix no. 1, Budget for 1883, 21 November 1882 .
} 
with Henry A. Jackson, the director of the Cash Office in Sulina and a veteran employee, who resigned in protest at the commissioner's excessive zeal. ${ }^{13}$ Maxime's colleagues were not impressed with his highly critical account and paid equal attention to employees' complaints. Things eventually cooled down when the Ottoman commissioner was removed from his position by his government. The episode is relevant in illustrating the balance that was preserved between the Commission's legislative-managerial layer (commissioners) and the bureaucratic-executive one, consisting of the organisation's chiefs of services, who were competent professionals, usually with lifelong experience in the organisation.

\section{The Internal Administration of the Commission}

The Commission reorganised its internal administration several times, and its staff was employed in one of seven services that coordinated the activities deemed vital for the security of navigation along the Maritime Danube.

Over the decades, the responsibilities of the Secretariat were clarified and codified, and the secretary general was placed under the direct authority of the Executive Committee, which ran the Commission's daily business. The secretary general assisted the Administration Delegate in his functions and even replaced him in case of absence. He resided at the Commission's main headquarters in Galați (Fig. 12) and oversaw drafting, printing and distributing protocols of plenary sessions and other official publications. He attended the plenary sittings and the meetings of the Executive Committee and was responsible for the execution of decisions. He sent monthly reports to non-resident delegates and oversaw all institutional correspondence and the Commission's archive and library. ${ }^{14}$

The position of secretary general was an influential and well-paid one. Mohler remained in office, with a break of several years, for almost two decades (1857-1873, 1879-1883). He graduated from a French law school and, given his duties, became well-versed in international law and fluvial shipping. In fact, he deserves a lot of credit for the organisation's bureaucratic efficiency. Given the need for a perfect command of French, Frenchmen had been usually appointed to this position. Several interesting characters held it until the First World War. August Gauvain, for example, was a distinguished French

\footnotetext{
13 TNA, FO 881/5874, f. 1 (Consul-General Percy Sanderson to the Marquis of Salisbury, Galați, 3 December 1889) and f. 2-7 (Report by the Turkish Commissioner, with Observations thereon).

14 La Commission, 82-85.
} 
journalist and diplomat. He studied law and worked as editor for the Journal des débats before joining the Commission in 1892. He remained in Galați until 1903, when he was appointed secretary of the Central Office for International Transport by Railways in Bern. The organisation was inaugurated in 1893 for the internationalisation of cargo traffic, ${ }^{15}$ and Gauvain's prior expertise in an IO might have helped him get the job. He returned to journalism as an expert in international relations and wrote extensively about the Eastern Question and the Great War. ${ }^{16}$ J.M. Savoye, Gaston Donnet and Gustave Demorgny, who succeeded him, followed similar professional paths, becoming experts in international rivers, and made good use of their direct knowledge of the Eastern Question. They may be good examples to fit into the growing category of experts in international rivers, part of influential transnational communities of professionals who used their expertise to influence decision-making in states, IOs or private companies. ${ }^{17}$

Comparisons with other early IOs are useful and may illuminate the role of bureaucracy in the efficiency of such organs. The Central Commission for the Navigation of the Rhine had a complex secretariat with eight employees as early as $1816,{ }^{18}$ but it never became as influential as the Commission. The International Telegraph Union, on the contrary, owed its development to the establishment of a permanent central secretariat under a very diligent director, Charles Louis Curchod. ${ }^{19}$

The Commission's fiscal services evolved in relation to the organisation's financial independence. In 1856, a Prussian accountant, Rüthling, was appointed to watch over the organisation's funds and act as cashier at the Central Office in Galați. Two branches were later opened in Sulina and Tulcea for local financial operations, and a Cash Office (or Navigation Chest) was established in Sulina for collecting navigation dues. Bureaucratic experiments were made during the following decades, and financial coordination moved

15 A. Waldis, 'Internationale Eisenbahnorganisationen und die Schweiz,' in: M. Burri et al. (eds.), Die Internationalität der Eisenbahn 1850-1970 (Zürich 2003), 245-256.

16 For information on his life and public works, see his profile http://data.bnf.fr/12768819/ auguste_gauvain/ (visited on 17 March 2018).

17 Peter M. Haas, 'Introduction: Epistemic Communities and International Policy Coordination, International Organization 46.1 (1992): 1-35; Mai'a K. Davis Cross, 'Rethinking Epistemic Communities Twenty Years Later', Review of International Studies 39.1 (2013): 137-16o.

18 Jean-Marie Woehrling, 'Ladministration de la Commission Centrale pour la Navigation du Rhin,' Revue française d'administration publique 126.2 (2008): 346, note 7.

19 Simone Fari and Gabriele Balbi, 'Curchod, Charles Louis', in IO BIO, Biographical Dictionary of Secretaries-General of International Organizations, edited by Bob Reinalda, Kent J. Kille and Jaci Eisenberg, online at www.ru.nl/fm/iobio (visited on 15 January 2019). 


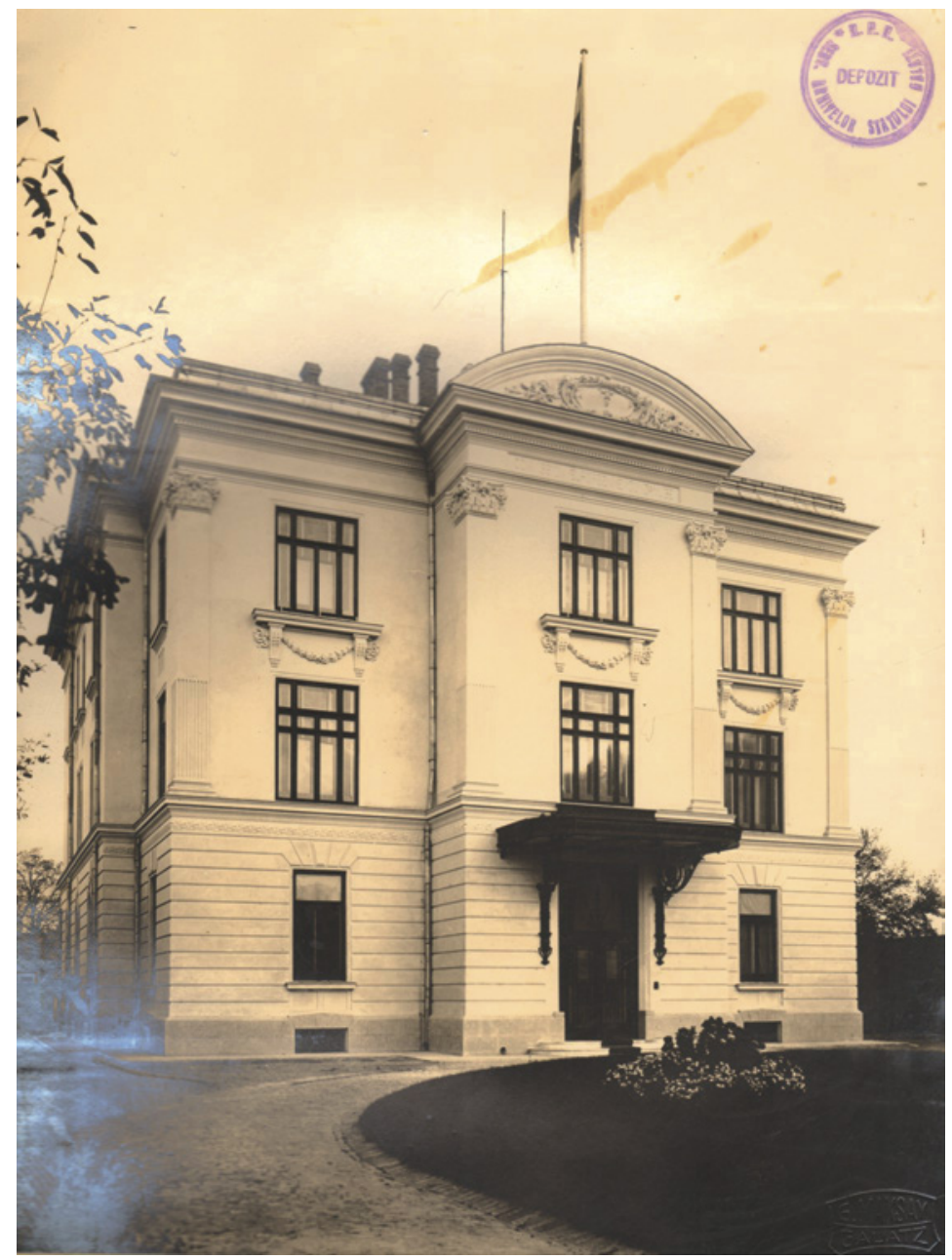

FIGURE 12 The Commission's palace in Galați (1930)

SOURCE: NATIONAL ARCHIVES OF ROMANIA, GALAȚI BRANCH

between Sulina, where taxes were collected, and Galați, where payments were made and accounting records kept. Structural changes were imposed by the need to have trustworthy employees in charge of these services. From 1879, an Accounting Service, based at the Commission's headquarters in Galați, was responsible for all financial operations. Its employees dealt with revenues and expenditures, from drawing up the annual budget to the conclusion of payment orders. Financial transactions carried out by the director of the service were approved by the Commission, and the Finance Delegate in the Executive Committee was responsible for directing and overseeing all aspects of the 
Commission's financial business. ${ }^{20}$ Until the First World War, this service was directed by three Germans, an Austrian, a Frenchman and a Brit, all trustworthy and experienced employees of the organisation (see Table 5).

At Sulina, the Navigation Chest was managed by a director nominated by the Commission and acting under its exclusive orders, although financial operations were audited by an official appointed by and acting on behalf of the Ottoman government. This changed after 1878 , when the Commission became an independent organ and could conduct its own audits. The Navigation Chest collected different types of taxes, from navigation tolls and fines to taxes for the Health Office. It also compiled statistics about the trade and navigation of the Maritime Danube, and provided monthly and quarterly statistical reports, published as abstracts in the Commission's annual statements. The director of the Navigation Chest oversaw the Commission's administrative headquarters in Sulina. ${ }^{21}$

\begin{tabular}{llll} 
Service & Chief & Nationality & Period \\
\hline General Secretariat & E. Mohler & France & $1857-1873$, \\
& & & $1879-1883$ \\
& E. de Wolf & Germany & $1874-1878$ \\
& Henri Bellanger & France & $1888-1892$ \\
A. Gauvain & France & $1892-1903$ \\
J.M. Savoye & France & $1903-1906$ \\
Gaston Donnet & France & $1906-1908$ \\
Accounting & Gustave Demorgny & France & $1908-1911$ \\
& Francis Rey & France & $1911-1938$ \\
& Ruthling & Prussia & $1857-1861$ \\
& E de Wolf & Prussia & $1861-1865$ \\
& E. Sulzer & Austria-Hungary & $1866-1873$ \\
& E de Wolf & Germany & $1874-1891$ \\
& W. Eagle & Great Britain & $1891-1906$ \\
Ch. Forgués & France & $1906-1911$ \\
& F. Keim & Germany & $1912-1915$
\end{tabular}

20 La Commission, $85^{-88}$.

21 Ibid., 88-9o. 
TABLE 5 Heads of the Commission's services, 1856-1916 (cont.)

\begin{tabular}{|c|c|c|c|}
\hline Service & Chief & Nationality & Period \\
\hline \multirow[t]{7}{*}{ Navigation Chest } & Jacobsen & Belgium & $1860-1869$ \\
\hline & E de Wolf & Prussia/Germany & $1869-1873$ \\
\hline & H.A. Jackson & Great Britain & $1874-1889$ \\
\hline & W. Eagle & Great Britain & $1889-1891$ \\
\hline & A. Velasty & Romania & $1891-1904$ \\
\hline & P. Keim & Germany & $1904-1911$ \\
\hline & G. Mateucci & Italy & $1912-1931$ \\
\hline \multirow[t]{3}{*}{ Technical Service } & Ch. Hartley & Great Britain & $185^{6-1871}$ \\
\hline & Karl Kühl & Denmark & $1872-1907$ \\
\hline & E. Magnussen & Denmark & $1908-1919$ \\
\hline Navigation & F. Drygalski & Ottoman Empire & $1861-1877$ \\
\hline \multirow[t]{4}{*}{ Inspectorate } & Ch. Dethier & Germany & $1878-1897$ \\
\hline & F.C. Horn & Germany & $1897-1902$ \\
\hline & G. Neitzke & Germany & $1902-1905$ \\
\hline & H. Lienau & Germany & $1905^{-1916}$ \\
\hline \multirow{12}{*}{$\begin{array}{l}\text { Harbour Master's } \\
\text { Office }\end{array}$} & Hussein Bey & Ottoman Empire & 1857 \\
\hline & Ahmed Bey & Ottoman Empire & 1857 \\
\hline & Jacoub Captan & Ottoman Empire & 1857 \\
\hline & $\begin{array}{l}\text { Costaki Effendi } \\
\text { (C. Sartinski) }\end{array}$ & Ottoman Empire & $1857-186 o$ \\
\hline & Fotius & Ottoman Empire & $1860-1863$ \\
\hline & Suleiman Effendi & Ottoman Empire & $1863^{-1865}$ \\
\hline & Ahmet Bey & Ottoman Empire & $1865^{-1875}$ \\
\hline & Mehmed Bey & Ottoman Empire & $1875^{-1877}$ \\
\hline & Ali Sinan Effendi & Ottoman Empire & $1877-1879$ \\
\hline & D. Pavlovich & Austria-Hungary & $1879-1896$ \\
\hline & C. Suhor & Austria-Hungary & $1896-1903$ \\
\hline & F. Wilfan & Austria-Hungary & $1903^{-1918}$ \\
\hline \multirow{7}{*}{$\begin{array}{l}\text { Medical Service } \\
\text { (after } 1902 \text { also } \\
\text { included a chief } \\
\text { surgeon) }\end{array}$} & Engelhardt & France & $1857-185^{8}$ \\
\hline & Jellinek & Prussia / Germany & $185^{8-1870}$ \\
\hline & Vignard & France & $1870-1887$ \\
\hline & Romalo & Romania & $1887-1890$ \\
\hline & Petrescu & Romania & $1890-19^{21}$ \\
\hline & G. Rolando & Italy & $1902-1905$ \\
\hline & G. Martone & Italy & $1905^{-1921}$ \\
\hline
\end{tabular}

SOURCE: LA COMMISSION EUROPÉENNE DU DANUBE ET SON CEUVRE DE 1856 À 1931 (PARIS 1931), 104-107, AMENDED WITH OTHER INFORMATION 
The Technical Department was formed in 1856 to cope with the Commission's hydraulic task. It was the Commission's most complex service and had a flexible structure, often being reorganised according to institutional needs. Over the following decades, it was to include, besides the staff employed in engineering works at Sulina and along the river, labourers working at the stone quarries in Dobrudja and the Commission's workshops in Tulcea and Sulina. In 1862, it had an engineer-in-chief, his assistant engineer and a surveyor based in Sulina. Five employees worked at the Tulcea workshops, three of whom dealt with the reception and transportation of stone from the Dobrudja quarries, while three others were employed at the Sulina workshops. By 1882, the Technical Department, a veritable 'hydraulic bureaucracy',22 had two engineers, a deputy engineer, a mechanical inspector, a draftsman, a secretary accountant and two clerks. ${ }^{23}$

As briefly mentioned in Chapter 4, Hartley decided to retire in 1871 , but continued to oversee the works as consulting engineer. He was to advise on the measures to be taken along the Danube and at the Sulina mouth, and, if necessary, on the opening of another mouth for navigation. He was assisted by a resident engineer, who was the head of the Technical Department and served as an interface between Hartley and the Commission. However, as part of the staff, the resident engineer was responsible for all technical and financial aspects related to the Commission's hydraulic programme. A Danish engineer, Charles (Karl) Leopold Kühl, held this position at the organisation's base in Sulina. According to later instructions, the resident engineer was responsible for maintaining the navigability of the river and its proper signalling by buoys and other navigational aids. He was in charge of the construction, maintenance and repair of the organisation's buildings and properties (offices, dwelling houses and the workshops in Galați, Tulcea and Sulina), as well as the maintenance of its floating equipment (boats, dredges, barges and pontoons) and its lighthouses. Kühl remained in office until 1907, when he replaced Hartley as consulting engineer. His position was filled by another Danish engineer, Eugene Magnussen, a long-time employee of the Commission. ${ }^{24}$

The Commission felt the need to provide medical assistance to its employees because of the unhealthy climate and absolute lack of medical facilities in the Danube Delta region. Two hospitals, one at Tulcea and the other at Sulina,

22 F. Molle, P. Mollinga and P. Wester, 'Hydraulic Bureaucracies and the Hydraulic Mission: Flows of Water, Flows of Power,' Water Alternatives 2.3 (2009): 328-349.

23 PECD, Protocol 151, appendix no. 2, Budget for 1863, 13 November 1862 and Protocol 399, appendix no. 1, Budget for 1883, 21 November 1882.

24 La Commission, 90-94. 
were set up as early as 1857 by what became the Commission's Medical Service. The Tulcea hospital was closed in 1865 , when the organisation ended the activity of its technical workshops in Tulcea, but the Sulina hospital was further developed to serve the medical needs of the organisation's staff and their families, local inhabitants, and seafarers of all nations. More details about its activity will be provided in Chapter $9 .{ }^{25}$

The Harbour Master Office in Sulina was vital for the success of the Commission's mission, as one of its two executive agencies. In February 1857, when the Ottoman Empire took over sovereignty in the Danube Delta, the Commission concluded an agreement with the Porte, aiming to settle the appointment and attributions of the officials responsible for regulating Danube navigation. Despite an apparent initial understanding, disputes followed in relation to how the Captain of the Port was to be nominated and paid. ${ }^{26}$ Hussein Bey became the first Captain (appointed by the Porte, and accepted by the Commission), and received detailed instructions as to his duties from the IO. His office was to consist of an interpreter, a treasurer, several clerks and the crews to work on board several service ships placed at his disposal. The office was open from sunrise to sunset, and was required to monitor shipping within the roadstead and port of Sulina. The Captain also supervised the corps of pilots, lighterage operations and the lighthouse service, and the treasurer was entrusted with cashing in the taxes for pilotage and the lighthouse service. ${ }^{27}$ The nomination procedure and salaries for staff were fixed during a subsequent session, ${ }^{28}$ and a provisional regulation for the port police and roadstead was drafted in June 1857. The port was divided into five sections, each to host a special type of maritime operation, and clear navigation rules were introduced (see below). ${ }^{29}$

Not long after his appointment, Hussein was in open conflict with the commissioners, after the cashier of Sulina's Master Office, a certain Radeglia, accused Hussein of embezzlement and blackmail. Hussein allegedly appropriated

25 Ibid., 102-103.

26 PECD, Projet d'arrangement destiné à régler les rapports de la Commission Européenne du Danube avec l'Autorité territoriale, appendix to Protocol 12, 4 February 1857; discussions also in Protocols 13 to 16, 4 to 26 February 1857; La Commission, 98-99.

27 PECD, Instructions provisoires pour le capitaine du port de Soulina, appendix to Protocol 17, 28 February 1857.

28 Ibid., Protocol 20, 27 March 1857.

29 The first version was Projet de Règlement Provisoire pour la police du port de Soulina, appendix to Protocol 33, 10 June 1857, later modified by Dispositions complémentaires au Règlement Provisoire pour la police du port de Soulina, appendix to Protocol 106, 19 October 1859 and Règlement Provisoire pour la police du port et de la rade de Soulina, Protocol 117, 9 July 1860. 
the tax paid by several skippers and instructed the cashier to falsify the official ledgers. Commissioners started an investigation and found him guilty. The Ottoman commissioner, however, rejected the sentence until a 'proper' inquiry could be conducted by representatives of the Ottoman government, who found Hussein innocent. ${ }^{30}$ This increased the mistrust of 'European' commissioners in Ottoman officials and motivated them to look for employees not contaminated with 'Oriental' mores. An opportunity came soon enough, with the creation of a new office - that of Inspector of Navigation.

According to the 1856 Paris Treaty, the Riparian Commission had to draft navigation regulations for the entire Danube. However, as the western victors rejected Austria's hydro-hegemonic intentions, visible in the Riverain Commission, the Commission analysed the possibility of appointing an agent for monitoring navigation and imposing its rules over the river section between Isaccea and Sulina. ${ }^{31} \mathrm{~A}$ regulation for the creation of this executive agency, the Inspectorate General of Navigation, was presented in May 1861, ${ }^{32}$ to which the Ottoman commissioner consented with several amendments. ${ }^{33}$ As mentioned above, Drygalski was appointed as head of this Inspectorate, supported by several overseers (superintendents) placed along various sections of the river. Drygalski took an oath to serve the Commission, the first oath to be taken by an international civil servant. The ${ }_{1865}$ Public Act clarified the double subordination of the Captain and of the Inspector: they were named and paid by the Porte, in whose name they exercised their authority, but they acted under the superintendence of the Commission. ${ }^{34}$

This system was changed after 1878 . Following the Treaty of Berlin, the new Inspector of Navigation was appointed and paid by the Commission, which could also dismiss him. Additional regulations defined the duties of the two

$30 \quad$ PECD, Protocols $32(6,9,12,24$ and 29 June 1857) and 46 (21 July 1857).

$31 \quad$ La Commission, 95.

32 Several regulations were drafted for the area: Projet d'un Règlement provisoire pour la police de la navigation sur le Bas Danube, entre Isaktcha et Soulina, appendix to Protocol 110, 12 November 1859; Règlement provisoire pour la police de la navigation sur le Bas Danube, entre Isaktcha et Soulina, appendix to Protocol 115, 27 June 1860; Règlement sur la création d'un inspectorat général de navigation pour la partie du Danube situé en aval d'Isaktcha, appendix to Protocol 126, 1 May 1861; Règlement provisoire sur la création d'un inspectorat général de navigation pour la partie du Danube située en aval d'Isaktcha, Protocol 138, 2 October 1861; Règlement provisoire de navigation et de police applicable au Bas Danube, Protocol 162, 15 July 1864.

33 The opinion of the Ottoman commissioner in Türkiye Cumhuriyeti Cumhurbaşkanlığı Devlet Arşivleri Başkanlığı (Republic of Turkey Presidential State Archives, formerly known as Başbakanlık Osmanlı Arşivi), i..HR 186/10349 (21 M 1278) (29 July 1861). 
executive services of the Commission: the Inspectorate of Navigation and the Sulina Harbour Master Office. The former was run by the Inspector of Navigation, entrusted with overseeing the navigation police of the Maritime Danube, exclusive to the port of Sulina. He was responsible for applying the Commission's navigation and police regulations and, in the event of a contravention, to prosecute and convict the offenders as a judge of first instance. He organised the river pilotage service, intervened in cases of emergency and coordinated hydrographical surveys along his jurisdiction. His residence was at Tulcea, halfway between Galați and Sulina, and in the discharge of his duties was assisted by a deputy inspector, several clerks and four river superintendents, stationed at different points along the Danube, who watched over the good conduct of navigation regulations and ensured that the river was properly signalled. ${ }^{35}$ The Sulina Captain had similar attributions over its jurisdiction, the harbour and roadstead of Sulina. He coordinated the local pilots, the lighthouse and fog service, and oversaw the ship gauging department. ${ }^{36}$ In 1882, the Inspectorate of Navigation had twelve employees, and the Harbour Master Office ten employees, plus twelve guards for the lighthouses maintained by the Commission. ${ }^{37}$

This very complex bureaucratic system evolved in time and was fully functional by the late 1870 s, when the Commission became an independent IO. As visible in Table 5 , the Commission's seven services were headed by a relatively low number of people. Each chief spent on average almost a decade in charge of his service, but some of them remained for their entire professional life in the organisation and became veritable models of corporate expertise. It can be concluded that the bureaucratic structure solidified the organisation into an efficient institution through promotion procedures which privileged loyalty to the Commission and seniority in the organisation.

\section{In Search of Juridical Powers}

European commissioners discussed several times the possibility of establishing a Mixed Court for dealing with infractions committed by foreign nationals in relation to lighterage operations within the Commission's jurisdiction. When organising navigation on the Maritime Danube, it was unclear, given the nature of the Capitulations and the attempts of the Commission to overrule

$35 \quad$ La Commission, $96-98$.

36 Ibid., 100-102.

37 PECD, Protocol 399, appendix no. 1, Budget for 1883, 21 November 1882. 
the authority of local consuls, which tribunal would decide in cases of theft committed by lightermen to the detriment of shipmasters. Stokes proposed establishing a Mixed Court to judge all contestations to the application of the Commission's regulations. It would be made up of members of the consular corps from Sulina and of navy officers from the light warships stationed there. The chief of the local Ottoman administration, the kaymakam of Sulina, would serve as president, and the court could include between two and six members. The consul of the defendant's party would assist at the trial, and the Captain of the Port of Sulina would act as public attorney. Stokes submitted the proposal to his government, which rejected it, as it constituted 'a serious innovation in the public law consecrated by the Capitulations. ${ }^{38}$

Discussions returned in 1861 when France's Édouard-Philippe Engelhardt proposed the establishment of a free port at Sulina. One of the institutions there needed to establish, as in the case of the Central Commission for the Navigation of the Rhine, ${ }^{39}$ a special jurisdiction for all navigational litigations. This could be a mixed judiciary commission, based at Sulina and called to take decisions in cases of commercial disputes between foreigners. Austria's Franz Karl von Becke supported the idea, and the commissioners decided to discuss it with the members of the consular corps and see if it fitted with the different jurisdictions overlapping Ottoman territory according to the Capitulations. ${ }^{40}$

From 1861, with the creation of the Inspectorate and the nomination of Drygalski, the Commission served as a de facto Mixed Court, as the commissioners judged appeals against decisions of the agents charged to execute the Commission's regulations. ${ }^{41}$ The 1865 Public Act consecrated the Commission as a court of appeal when the sentences of the two executive agents (as judges of first instance) were contested. Attempts to create a more elaborate Mixed Court continued, and in 1867 the Austrian commissioner, Alfred de Kremer, raised the issue of which court was to judge cases of damage to the Commission's works and properties. His own version of the Mixed Court was made up of three commandants of warships, who rotated their positions. It would be responsible for judging juridical cases by making nautical

38 Ibid., Protocol 85, 24 September 1858.

39 For the juridical powers of the Central Commission for the Navigation of the Rhine, see Joseph P. Chamberlain, The Regime of the International Rivers: Danube and Rhine (New York 1923), 186-187, 301-303 and Henri Walther, 'La révision de la Convention de Mannheim pour la navigation du Rhin,' Annuaire Français de Droit International 11.1 (1965): 815-818.

$40 \quad$ PECD, Protocol 132, 29 June 1861.

41 Ibid., Protocol 141, 30 November 1861. 
appreciations and assessing the circumstances of major force and damages to be paid. ${ }^{42}$ However, Stokes voted against it, at his government's instruction. ${ }^{43}$ This, of course, had to do with decisions of a navigational nature relating to violations of the Commission's regulations, not any other types of crimes.

An example is perhaps relevant for the workings of the Commission's complex bureaucracy and for its juridical activity. On 9 April 1880, the Flora, a packet owned by the Austrian-Hungarian Lloyd, was travelling downstream the river. The weather was foggy, and in a dangerous bend of the river its captain considered it advisable to go from the left to the right bank and signal from time to time, according to shipping procedures. While crossing the river, the Flora struck the British steamer, the Barita, and the force of the collision sank the latter in about five minutes. Six people drowned in the tragic accident. The Inspector of Navigation, Charles Dethier, proceeded to the site the next day and then to Galați, to interview the survivors. He included in his initial report two written statements from the two registered pilots (Andrea Lucovich and Dimitri Musaki) of the Commission, who were on board the two ships. According to regulations, they had to report on the accident to their chief. Dethier further included in his report the statements of the two shipmasters and interviews with the two pilots. His report was completed on 11 April, but a decision was difficult, as the two parties involved had opposite versions of the accident. Dethier considered the captain of the Flora to be blameless, as he had followed the Commission's regulations exactly. At the request of the Commission's bureaucratic management, the Inspector conducted a further investigation and drafted a second report on 26 April. He interviewed twentyfour people who were on board the Flora, including the Commission's pilot, and four members of the Barita crew. Based on all these documents and the testimonies of three fishermen who happened to be close to the site of the disaster, Dethier concluded that the captain of the Barita was the guilty party, as he did not obey the Commission's regulations. Captain Lambert was guilty of not abiding to articles 32, 34 and 35 of the Commission's Regulation of Navigation and was fined 150 francs.

Lambert appealed the decision, alleging that the fishermen were making false allegations and had been bribed to testify against him. The commissioners judged the appeal and reached the same verdict as Dethier. The two parties involved their consulates in the dispute and, at a meeting of the Commission, British commissioner Herbert Taylor Siborne claimed that the master of the Flora had failed to comply with the directive to slow down. Further remarks

42 Ibid., Protocol 198, 2 November 1867.

43 Ibid., Protocol 210, 21 April 1868. 
concerned weather conditions on that day, as regulations stated that ships had to stop when visibility was low. But the biggest problem was that derived from the Commission's authority in relation to its own executive agents. Siborne contended that the Inspector had neglected one of the essential elements of the investigation and failed to consider fully the circumstances of the incident. Commissioners discussed the issue and the Inspector's powers, but no decision was taken, and individual governments subsequently reached their own conclusions. ${ }^{44}$ The French government, for example, analysed the case in its national commission for disasters, which agreed that the Barita was the guilty party. ${ }^{45}$

This is one of the cases which the Inspector of Navigation judged in the first instance, and the Commission as the court of appeal. The organisation had instituted fines for offences against the provisions included in its regulations, which varied between 10 and 50 francs. There were also fines for abusive language and assaults against the Commission's executive agents. Maximum fines could be doubled in cases where the infraction was repeated, and skippers were personally responsible for the offences committed by their crews. Appeals against the agents' sentences were judged by the Commission, which acted as a court of appeal when at least three commissioners were present. ${ }^{46}$ Both executive agents were kept busy by a multitude of incidents. Between 1862 and 1890, 93 cases alone occurred in the jurisdiction of Tulcea. Most of the cases, however, consisted of minor infractions, such as anchorage in forbidden places, refusal to leave those places and blocking the navigable channel. ${ }^{47}$ According to available sources, shipmasters generally respected the Commission's authority, which had established a sense of order and predictability that served their economic interests.

Although less known then the Mixed Courts of Egypt, ${ }^{48}$ this transnational juridical system emerged from the same sort of rationality aimed at regional economic development. As the existing juridical system was unequipped for the busy trade and shipping of an international transportation infrastructure

\footnotetext{
$44 \quad$ Ibid., Protocol 377, 3 January 1881.

45 Centre des Archives diplomatiques de La Courneuve, Représentant de la France auprès de la Commission Européenne du Danube, File 184, f. 402-403 (Camille Barrère to Saint Hilaire, Galați, 17 June 1881).

46 PECD, Acte public, 2 November 1865, Annexe A, Règlement de navigation et de police applicable au Bas-Danube, Titre VI, Des contraventions (art. 98-111).

47 The Hague - Permanent Court of International Justice Publications, vol. 13-4-2, Jurisdiction of the European Commission of the Danube between Galatz and Brăila (PCIJ ser. C, [7]) (Leiden 1927), 525-528.

48 Mark S.W. Hoyle, The Mixed Courts of Egypt (London 1991).
} 
regulated by an IO, the Commission experimented in regulatory matters and this played an important role in imposing juridical order in a periphery of the Ottoman Empire. The system was innovative and, in many ways, violated the sovereignty of the territorial powers, the Ottoman Empire and Romania. But it was a functional system and skippers and merchants were generally happy with the security regime, based on law and order, that the Commission had established along the Maritime Danube.

\section{The Modern Organisation of Pilotage}

The disorganised nature of pilotage had been one of the main complaints of seafarers during pre-Crimean War times, so the creation of a modern pilotage service was a top priority for the Commission. Already established by November 1856, in February 1857 it was subordinated to the Captain of the Port of Sulina. It became compulsory for all ships entering the Danube to take a local pilot on board, and provisional regulations for the pilotage service were drafted in March 1857. According to an updated version, pilotage was not only compulsory, but also a monopoly of the Commission, and sanctions were imposed in case of infraction. ${ }^{49}$

The corps of Sulina pilots (first-class pilots) consisted of a chief pilot, a deputy chief, 30 first-class pilots, and an undetermined number of auxiliary pilots. Suitable candidates had to prove, in addition to conditions of age and residence, experience aboard seagoing vessels, and had to pass an exam. Pilots wore a uniform and carried a notebook in which they recorded their activities. The pilotage tax covered the corps' administrative costs, necessary equipment (such as boats) and salaries. The amount collected was divided into sixtyseven equal shares, four parts being due to the chief pilot, three to his deputy, and two to each of the pilots. To safeguard their honesty, pilots were forbidden to accept any kind of material compensation or be involved in any type of local business. ${ }^{50}$

River pilots (or second-class pilots) had to comply with the same conditions of expertise and discipline. Piloting was optional for vessels going upstream, being mandatory only when travelling downstream. The price for this optional

49 PECD, Dispositions transitoires sur le pilotage à l'embouchure de la Soulina, appendix to Protocol 21, 31 March 1857; Règlement provisoire sur le pilotage sur le Bas Danube, appendix to Protocol 56, 9 October 1857 .

$5^{\circ} \quad$ Ibid., Règlement provisoire pour le pilotage sur le Bas Danube, appendix to Protocol 117 , 9 July 1860 . 
component was regulated by open market rules, but several conditions were set to avoid disputes. By 1859 , the Commission reorganised the corps of river pilots, later placed under the supervision of the Inspector of Navigation. ${ }^{51}$

The regulation of 1865 further detailed the activities of Danubian pilots. A description is useful to show the institutionalisation of procedures and the Commission's focus on navigational safety. The Sulina pilots were conveyed on board vessels coming towards the port from seawards as soon as the lookout on the lighthouse tower signalled their approach. When on board, they informed the ship captains of the depth of water on the bar, and the captains had to declare to the pilot the draught of water, and the tonnage of the lading of their vessels. Second-class pilots were placed under the authority of the Inspector General, and were directed by a chief pilot - who had three offices, in Galați, Brăila and Tulcea - and by a deputy residing in Sulina. Commercial vessels were not compelled to take a certified pilot when going up the river if the masters themselves effected the voyage, but in downstream navigation, vessels of above 60 tons, rafts or trains of wood had to take a qualified river pilot on board. The same was required for vessels above 60 tons going upstream without the master of the vessel on board. Masters were to arrange with river pilots their payment for piloting upstream, but in case of disputes a maximum amount was set. The pilotage tax for vessels going downstream was included in the navigation dues charged at Sulina. Disputes between certified pilots and shipmasters were judged by the Commission's two executive agents when their intervention was required. ${ }^{52}$

Pilots were a central institution of the security regime established by the Commission after 1856. Piloting in Russian times was depicted in bleak terms, as part of a system of banditry and corruption which steered vessels towards destruction rather than safety. The Commission invested a lot of energy in establishing a corps of well-trained and honest pilots, who were the organisation's most visible interface with its customers. It took a long time to establish this corps, which was eventually absorbed into the Commission's staff. As shipping experts with both indigenous and institutionalised knowledge of the river, they contributed to turning the Maritime Danube into a safer waterway.

51 Ibid.

52 Ibid., Règlement, 1865, Titre IV, Du service de pilotage à l'embouchure et dans le cours du fleuve (art. 69-81). 


\section{Regulating Lighterage Operations}

Before 1856 the lighter service had been one of the plagues of Danubian navigation, as the owners of lighters offered no guarantee of honesty and were often involved in theft. In addition, they acted arbitrarily in setting rates and enforcing their contracts. The Commission was quick in trying to regulate the service of lighters. In December 1856 a union of local lightermen even protested against the works of the Commission for threatening their business model. ${ }^{53}$

According to March 1857 instructions, the Captain of the Sulina port was to supervise the activity of the service and to judge disputes between the shipmasters and the owners of lighters. In September 1858 the Commission established a draft regulation for lighters, and debates followed on the creation of a Mixed Court to deal with theft by the owners of lighters. A provisional regulation was adopted on 26 July 1860, which further clarified the lightermen's activity. They had to register their vessels at the Harbour Master Office and be provided with a certificate issued by that institution. ${ }^{54}$

The 1865 regulation divided lighters on the Lower Danube into two classes: 1. those employed exclusively at the Sulina mouth or at any difficult passage along the waterway; and 2. those involved in lading at an interior port to discharge at Sulina or in its roadstead. No person could undertake any lighterage operation without a proper licence. A commission assessed the condition of the vessel and certified its capacity in tons and burden in kilos of Constantinople. This examination had to be repeated each year. Vessels furnished with regular ships' papers could be employed occasionally to lighter other vessels, but skippers were required to make a special declaration for each operation, and to deposit their papers either at the office of the Captain of Sulina or at the office of the Inspector General. 55

There were several clauses related to the honesty of the parties involved, and the Commission tried to invest in shaping the morality of Danubian entrepreneurs. Lighters were not permitted to have any vacant space in the hold except that which could be duly recognised by the Captain of the Port when the vessels were licensed. The shipmaster being lightered had the right to place, at his own cost, a guard on board the lighter he employed. No lighter could leave

\footnotetext{
53 Ibid., Protocol 7, 17 December 1856.

54 Ibid., Projet de règlement provisoire concernant le service des allèges sur le Bas Danube, appendix to Protocol 85, 24 November 1858; Règlement provisoire pour le service des allèges sur le Bas Danube, appendix to Protocol 118, 26 July 1860; details also in La Commission, 266-268.

55 Annexe A, Titre v, Du service des allèges (art. 82-97) of Acte public relatif à la navigation des embouchures du Danube signé à Galatz, le 2 novembre 1865 (Galați [1865]).
} 
the port of Sulina without the written permission of the Captain, and as a rule lighters had to leave the port together with the vessels that they had lightered. When the re-lading of goods was done on board the lightered vessel, the master was required to provide a written acceptance. ${ }^{56}$

In cases of presumed fraud or false statement of the capacity of the lighter, the master of the commercial vessel could request the verification of the tonnage by a commission specially designated by the Captain of Sulina or by the Inspector General. The examination cost was paid by the captain who required it, unless the inexactness or false declaration was proved, in which case it was paid by the owner of the lighter. If the captain of a vessel lightered had reason to believe that part of its cargo was fraudulently appropriated on board the lighter he chartered, he had to report it either to the Captain of Sulina or to the Inspector General, the Commission's executive officials who were to take the measures prescribed by their special instructions. If the suspicion was unfounded, the costs were paid by the captain of the lightered vessel. ${ }^{57}$

These rules, agreed upon by the representatives of the seven Great Powers, played a decisive role in 'civilising' Danube navigation and in introducing a climate of honesty in shipping operations in the Maritime Danube. If, in the case of piloting, the creation of a corps of professionals was the solution to removing corrupt practices, for lighterage the solution was to bureaucratise practices and to set up clear procedures and enforcing mechanisms. In the absence of strong state authorities in the Danube Delta, the Commission introduced a complex paperwork system that placed local business on more solid, documentary grounds. The Commission had good reason to boast about its success in 'taming' a service that had proved very detrimental to general navigation before 1856 .

\section{Pensions for International Civil Servants}

By the mid-186os, when it was decided that the Commission would continue for at least several more years, commissioners started to discuss the possibility of setting up a pension fund for the employees who had been in service for the last ten years. The proposal came from France's commissioner, Engelhardt, who considered that supporting the staff who had been working in difficult conditions at Galați and Sulina was itself an 'institution' meant to secure and

$56 \quad$ Ibid.

57 Ibid. 
facilitate navigation. ${ }^{58}$ However, the proposal was rejected by the Ottoman government, unwilling to negotiate such a possibility for a temporary commission. Discussions continued in the coming years, but to little avail.

In April 1868, eight of the most senior employees wrote a letter to the European commissioners. They had given up good careers in their countries to join an IO and to work in a harsh climate that affected their health. If such works had been done by a single European country, they claimed, employees would have undoubtedly enjoyed pensions from the respective state. They further referred to the example of the Rhine Commission, where employees were entitled to a pension, and decided to forward the request, quoted in the motto of this chapter, to their respective governments. ${ }^{59}$

Commissioners discussed a pensions project, but the Porte again opposed the establishment of such an indemnity. ${ }^{60}$ The Commission decided, however, to reward its long-serving employees upon their retirement, or upon the dissolution of the IO, with a financial bonus. ${ }^{61}$ Eventually, as the Commission was extended once more in 1871, the Ottoman commissioner, Ismail Bey, withdrew his opposition and accepted the pensions scheme, on condition that allowances were constituted by the creation of a special fund supplied by deductions from the employees' salaries. ${ }^{62}$

A regulation for the establishment of a pension fund for international employees was adopted in $1871 .{ }^{63}$ Employees could retire after a certain period of service, and received an allowance based on a deduction of 3 per cent of their income. Retirement was possible after ten years in some medical or social cases. The retirement indemnity was fixed as the average salary for the last five years of service multiplied by the years of service and divided by seven. A maximum of 30 years was considered, or 35 for those in top managerial positions. An increase of one seventh of a year per year was granted for those who resided at Sulina, where living conditions were worse than at Galați or Tulcea. The indemnity was paid directly to the employee, his widow or children. ${ }^{64}$ The pension scheme and other advantages mentioned below further consolidated

\footnotetext{
$58 \quad$ PECD, Protocol 173, 26 April 1865.

59 Ibid., Protocol 206, 15 April 1868.

6o Ibid., Protocols 221 and 226, 30 October 1868 and 21 April 1869.

61 Ibid., Protocol 230, 26 April 1869.

62 Ibid., Protocol 255, 25 April 1871.

63 Ibid., Protocols 259 and 261, 6 July and 1 November 1871.

64 La Commission, 109-114.
} 
the Commission as a functional organisation. The system was later used for other IOs, such as the League of Nations. ${ }^{65}$

\section{$7 \quad$ Categories of Staff and Their Immunities}

In the early phases of its history, the Commission engaged its employees through renewable short-term contracts, and changed their salaries according to very subjective decisions. In 1880 , the IO started to regulate the status of its staff through provisions of a more general and permanent nature, but it was only in 1884 that the eight commissioners established a table of all positions, divided them into classes and fixed the minimum and maximum salary for each employee. There were seven employees in the first class (the heads of the Commission's services), twelve employees in the second class (secretaries, archivists, chancellors, surveyors, assistant engineers, accountants and draftsmen), and twelve employees in the third class. Annual salaries varied between a minimum of 2,500 francs for some third-class employees and 20,000 francs, the maximum salary (to be earned after fifteen years of service) for the Commission's resident engineer. ${ }^{66}$

In the following decades, commissioners drafted and updated a 'Regulation for the classification, advancement and promotion of employees', accompanied by a table of salaries, called the 'Normal Table of Treatments'. As this system seemed arbitrary and led to numerous disputes, it was replaced by the classification of employees by the services they worked in. New regulations were voted for in the early twentieth century when the 'Normal Table' staff included 66 people. Even more detailed regulations fixed the recruitment, appointment and advancement of staff, as well as their salaries, indemnities, allowances, discipline rules and retirement conditions. ${ }^{67}$

The staff of the 'Normal Table' consisted of the bureaucrats employed in the Commission's services. Pilots, intermediary and lower staff were initially excluded from this privileged bureaucracy. The intermediary and lower staff consisted of employees such as foremen, shipmasters, guards, domestic servants, lighthouse keepers, sailors and workmen in the Commission's workshops and shipyards. The status of these categories of staff was regulated in 1906, when

65 Norman L. Hill, 'The Personnel of International Administration,' American Political Science Review 23.4 (1929): 972-988.

66 PECD, Protocol 413, 15 May 1884.

67 La Commission, 111-112. 
the Commission settled financial compensation to be granted at the cessation of their employment. ${ }^{68}$

The Commission was mostly interested in its bureaucratic structure and closely regulated the status of the staff in its 'Normal Table'. Over the decades, the organisation settled several advantages for its administrative and technical staff and for its pilots. They received, when employed, a flat-rate allowance to cover travel expenses for themselves and their families, furniture and installation costs in their Danubian residences. The Commission owned houses in Tulcea and Sulina, where some of its employees were accommodated. The others received a housing allowance, according to a variable rate depending on the employee's place of residence and their marital status. They were also provided with a heating allowance proportional to their salary and marital status. The Commission covered the expenses of its agents when travelling for official business. The reimbursement included travel costs, per diem and a daily allowance for hotels and incidentals. Special rules concerned the travel allowance for pilots and sailors. A flat-rate allowance was paid to allow employees to travel to their homeland during their yearly leave. An additional amount was granted for wives and children when they accompanied the employee. The Commission provided free medical care to all its staff, including temporary employees, and to their families. Medical assistance was given by the Commission's own medical staff in Sulina, and at Galați, Brăila and Tulcea by doctors approved by the organisation. Paid leave for sickness was also granted. Its duration varied depending on the employee's category. An extraordinary allowance was granted to the staff members who needed to travel abroad for health reasons, if certified by a doctor approved by the Commission. The IO could grant advances on salaries and wages in justified cases. Employees were entitled to have paid leave, but the greatest advantage was the retirement allowance granted to staff members who were of the age and seniority required by the regulations. ${ }^{69}$

Francis Rey, the long-standing secretary general of the Commission in the twentieth century and a member of the Institute of International Law, took a special interest in studying the status of international civil servants, and used his Commission knowledge to refer in detail to the rights and immunities of this new transnational bureaucracy. ${ }^{70}$

\footnotetext{
68 Ibid., $116-119$.

69 Ibid., 111-113 and 330-333. More on this in Gabriela Vulpe, 'Aspecte sociale ale activității Comisiei Europene a Dunării,' Acta Bacoviensia 5 (2010): 231-240.

70 Francis Rey, 'Les Immunités des Fonctionnaires Internationaux,' Revue de Droit International Privé 23 (1928): 265-267.
} 
Many of the early employees of the Commission came by invitation, according to an initial agreement among the maiden commissioners. In subsequent years, procedures for advertising available positions were set up. Staff already in service were generally preferred for promotion, and new people were employed through open calls for applications disseminated throughout Europe.

There was no quota for member states, and usually employment and promotion of staff went smoothly in the plenary sessions of the Commission. However, several incidents occurred, which are relevant in showing how an early IO operated. Such a dispute was sparked by the appointment of a second marine surveyor (officiervérificateur) which the Commission wanted to employ to survey the tonnage of the increasing number of steamers that plied on the Maritime Danube in the late 1870 . The British commissioner Herbert Taylor Siborne recommended a young candidate, Reginald Neate, for the post but the Executive Committee preferred to promote a certain Angelo Corsanego, a bossman or sub-inspector of the port of Sulina. Corsanego had 'a merchant captain's certificate and was of mature age', but was preferred because of his experience and seniority within the organisation. Siborne considered Neate to be more competent at surveying ships, but eventually he had to yield to his colleagues' choice. ${ }^{71} \mathrm{~A}$ further dispute concerned the first surveyor, a German employee named Boy, whose status the German commissioner, Johannes Arendt, wanted to exalt and thus remove him from the subordination of the British-led Cash Office. ${ }^{72}$ This dispute was also solved by a compromise.

By 1889, the Italian government proposed Commendatore Carlo de Amezaga, 'ex-Deputy, retired Captain Royal Italian Navy', for the post of secretary general, as 'no Italian has yet been among higher officials of the Commission'. Discussions of principles followed, with the French commissioner, the Marquis of Reverseaux, stating that the Commission 'should look to capacity and length of service more than to nationality'. Several commissioners felt there was no immediate need to fill up this post, which had been vacant for some time. Britain's Percy Sanderson also contended that it was not possible to keep an exact proportion between the nationality of employees and the amount contributed to the Commission's budget by the shipping of that country, as the Italian commissioner, G. Pascali Corte, seemed to have implied. In such a scenario, the English should account for 70 per cent of the staff. The proposal was

$\begin{array}{ll}71 & \text { TNA, FO 881/3876, f. 1-4 (Memorandum). } \\ 72 & \text { Ibid., FO 881/3984. }\end{array}$ 
eventually rejected, ${ }^{73}$ but in the coming years Italian and Romanian subjects were appointed to head some of the Commission's services.

\section{$9 \quad$ Administrative Works in Favour of Navigational Safety}

The Commission assumed the difficult task of transforming the river into a modern waterway by its activity in two main areas: undertaking necessary engineering works to remove physical obstructions and imposing a set of regulations in a region that hitherto had lacked any kind of modern shipping legislation. As much as Hartley's hydraulic works in Sulina transformed Danubian navigability, these rules and the enforcing institutions were equally important in contributing to the establishment of a security regime for international shipping. ${ }^{74}$

The Captain of Sulina and Inspector General were responsible for enforcing a complex set of regulations on the Lower Danube, the most important of which were related to navigational safety. Vessels arriving from sea and entering the Sulina roadstead were required to hoist the national flag and to respect the regulations imposed by the Commission. Ships had to anchor in the place indicated by the chief or sub-chief of the pilots of Sulina, and the shipmaster or his second officer had to present the ship's papers at the Harbour Master Office. No vessel of more than 60 registered tons could cross the bar at Sulina without a pilot licensed by the local authorities (steamers making regular voyages could use their own pilots). If, owing to stormy weather, the bar was judged impassable, a blue flag was hoisted on the tower of the lighthouse to show that the pilots were unable to meet vessels in the roadstead..$^{75}$

As for navigation along the rest of the Maritime Danube, vessels were forbidden to pass if going in the same direction, while those sailing in opposite directions were not permitted to cross in places where the channel did not afford sufficient breadth. When two vessels met while proceeding in different directions, the one ascending the river had to steer towards the left bank, and the vessel descending towards the right bank, so that both went to starboard, as was customary at sea. It was the same if the meeting took place between a steamship and a sailing vessel navigating with a fair wind. When a steamer wished to pass another going in the same direction, it had to signal before

\footnotetext{
73 Ibid., FO 881/5874, 8 (Salisbury to Sanderson, London, 20 May 1889).

74 For some more theories of international relations 'security regimes,' see Robert Jervis, 'Security Regimes,' International Organization 36.2 (1982): 357-378.

75 PECD, Annexe A, Règlement de navigation et de police applicable au Bas-Danube, Titre I, De la police de la rade et du port de Soulina (art. 7-24).
} 
doing so by means of five strokes on the bell or five whistles, and by waving a flag on the forecastle or by hoisting at half-mast a blue flag by day or a white light at night. Upon seeing these signals, the vessel in front had to steer to the left and allow the other to pass on the right. As soon as the vessel following was half a ship's length from the one it was about to pass, the latter had to slow down until it had been passed. Masters of heavily laden vessels, or of laden vessels of less than 60 registered tons, were required to keep out of the way of steamers as much as possible. ${ }^{76}$

Clear rules were also set for towage. ${ }^{77}$ The towing-path had to be kept free from all obstacles which hindered its use (such as bushes, trees, enclosures, houses or other constructions), and priorities were imposed for all cases that led to disputes: when vessels towed in opposite directions met on the same bank or when vessels towed by animals met vessels towed by men etc. As detailed were the rules for vessels at anchor, stipulating where they could moor and anchor. ${ }^{78}$

All steamships navigating between sunset and sunrise had to carry a white light that was easily visible at a distance of at least two miles, hoisted on the foremast head, as well as a green light on the starboard side and a red light on the port side. The green and red lights had to be fitted with inboard screens to prevent them from being seen across the bow. Sailing vessels underway or being towed had to carry the same lights as steamers except for the white foremast head light, which they were forbidden to carry. Steamers towing other ships had to carry two bright white masthead lights vertically, in addition to their side lights, to distinguish them from other steamships. Sailing vessels, convoys in tow and rafts were not permitted to navigate unless both banks of the river were visible at the same time. In fog, steamers had to reduce speed. In addition, the ship's bell had to be rung continuously, while a whistle had to be sounded every five minutes. Masters were required to anchor if the fog became so thick that they could not see the bank they were following or towards which they were steering. ${ }^{79}$

The rules concerning strandings and shipwrecks are also illustrative of how the Commission imposed modern legislation on the Maritime Danube in an

${ }_{76}$ Ibid., Titre II, De la police du fleuve, Chapitre II, Règles pour les bâtiments qui se croisent ou se dépassent (art. 26-37).

77 The first such regulation was Projet de règlement sur le halage dans la Soulina, appendix to Protocol 9o, 24 November 1858 .

78 PECD, Annexe A, Règlement, 1865, Titre II, De la police du fleuve, Chapitre III, Règles pour le remorquage (art. 38-39), Chapitre IV, Règles pour le halage (art. 40-46) and Chapitre VI, Règles pour les bâtiments au mouillage (art. 51-54).

79 Ibid., Annexe A, Règlement, 1865, Chapitre v, Règles pour la navigation pendant la nuit ou par un temps de brouillard (art. 47-50). 
attempt to reduce the frequency of such disasters. ${ }^{80}$ The captain of a vessel or raft grounded in the Sulina channel was bound to station a lookout to hail vessels and rafts coming downstream in order to acquaint them with the nature and place of the accident at least half a nautical mile upstream of that vessel. Steamers had to slow down to half-speed when passing places where a vessel or raft had run aground or foundered. The pilot was personally responsible if a wreck was caused by bad management. The captain and crew of a wrecked vessel were required to remain on board or on the bank near the spot where the accident took place until a detailed report was drawn up. Immediately after the wreck, the pilot was obliged to inform the Inspector General through his nearest superintendent. If the official considered it necessary to take immediate measures in order to safeguard navigation, he had to summon the captain of the wrecked vessel, who was then bound either to declare on the spot that he had abandoned his vessel or to act with his crew under the orders of the Inspector General who had to superintend salvage up to the point where the work ceased to be of public concern. ${ }^{81}$

The discharge of ballast on such a shallow river was also resolved. A provisional regulation was introduced in April 1857, as many vessels going upstream had been discharging ballast and thus creating additional navigational obstacles. In order to apply these rules on the entire Maritime Danube, the IO negotiated with the governments of the Principalities, and the regulation was implemented from 29 April 1858. The rules were supplemented in November 1862, and then included in the 1865 Public Act. ${ }^{82}$ Vessels were absolutely forbidden to throw ballast into the bed of the stream or into the road of Sulina, and it was equally forbidden to discharge it at sea in the neighbourhood of the roads at a bottom level of less than 60 English feet. The discharge of ballast on land outside the port of Sulina could only be effected on certain points of the bank determined by the Inspector General and indicated by public notice. To ensure the execution of these stipulations, every vessel in ballast leaving the port of Sulina on its way upstream had to be furnished with a certificate from the Captain of the Port 'stating the draught of water produced

8o Details in Constantin Ardeleanu, "The European Commission of the Danube and the Results of Its Technical and Administrative Activity on the Safety of Navigation,' International Journal of Maritime History 23 (2011): 73-94.

81 PECD, Annexe A, Règlement, 1865, Titre II, De la police du fleuve, Chapitre viI, Règles pour le cas d'échouement ou de naufrage (art. 55-63).

82 Ibid., Règlement provisoire sur le jet du lest, Appendix to Protocol 27, 27 April 1857; Projet de règlement provisoire sur le jet du lest, appendix to Protocol 78, 29 April 1858; Dispositions supplémentaires au règlement provisoire sur le jet du lest, du 29 avril 1858, appendix to Protocol 151, 13 November 1862; La Commission, 265-266. 
by the ballast'. This document was kept on board throughout the voyage, to be produced whenever required by the Inspector General or his agents. ${ }^{83}$

Another important aspect that the Commission regulated was the functionality of the lighthouses from the area of the western Black Sea coast. Lighthouses have always been an important means of ensuring navigational guidance and security for seafarers on the world's seas and oceans. Wherever it is built and maintained, a 'Pharos' is a marker of institutionalised navigation, a beacon that regulates shipping and keeps it on a safe track. In the Danube Delta, as huge quantities of alluvia carried each second by the Danube are deposited at the junction between river and sea, a lighthouse is a reliable landmark to make sense of a dynamic geography, in which everything, including river and land, moves and changes.

In 1856, the three lighthouses in the area (at Sulina, Serpent Island, and Schobler Sagui, south of St George) were administered by a French company that leased them from the Ottoman government. However, the Commission organised its own lighthouse service, and set a lighthouse fee in the navigation tolls it collected at Sulina. In 1867 , the commissioners learnt that the amounts it paid to the lessee were much higher than the cost of administering the respective lighthouses. The Commission reduced the duties to the amount needed to cover the real costs, and decided to no longer pay for the Schobler Sagui lighthouse, whose contribution to Danubian navigation was only indirect. ${ }^{84}$

In 1859, as shipping accidents occurred at the St George mouth of the Danube, the Commission decided to erect, at the southern end of the respective mouth, a lighthouse which would have the advantage of allowing ships to reach the Sulina mouth without being obliged to turn away from their route and follow the next mark, the Serpent Island. The lighthouse was built by the Commission's Technical Department in 1863 and was functional by May 1865 . From 1878, according to the provisions of the Berlin Treaty, the organisation claimed the administration and maintenance of the Sulina and Serpent Island lighthouses without waiting for the expiry of the concession, due in 1884. The concessionaires were compensated for their loss. ${ }^{85}$

Another important decision to facilitate navigation was the marking of the Sulina mouth by means of buoys, as detailed in Chapter 4. Finally, in 1857, the Commission organised a Rescue Service (Fig. 14) at Sulina and purchased a rescue boat. The pilots at the bar were employed for this purpose until November 1890, when the Commission adopted a Regulation for the Rescue

\footnotetext{
83 PECD, Annexe A, Règlement, 1865, Titre II, De la police du fleuve, Chapitre VIII, Règles pour le jet du lest (art. 64-65).

84 La Commission, 319-320.

85 Ibid., $320-323$.
} 

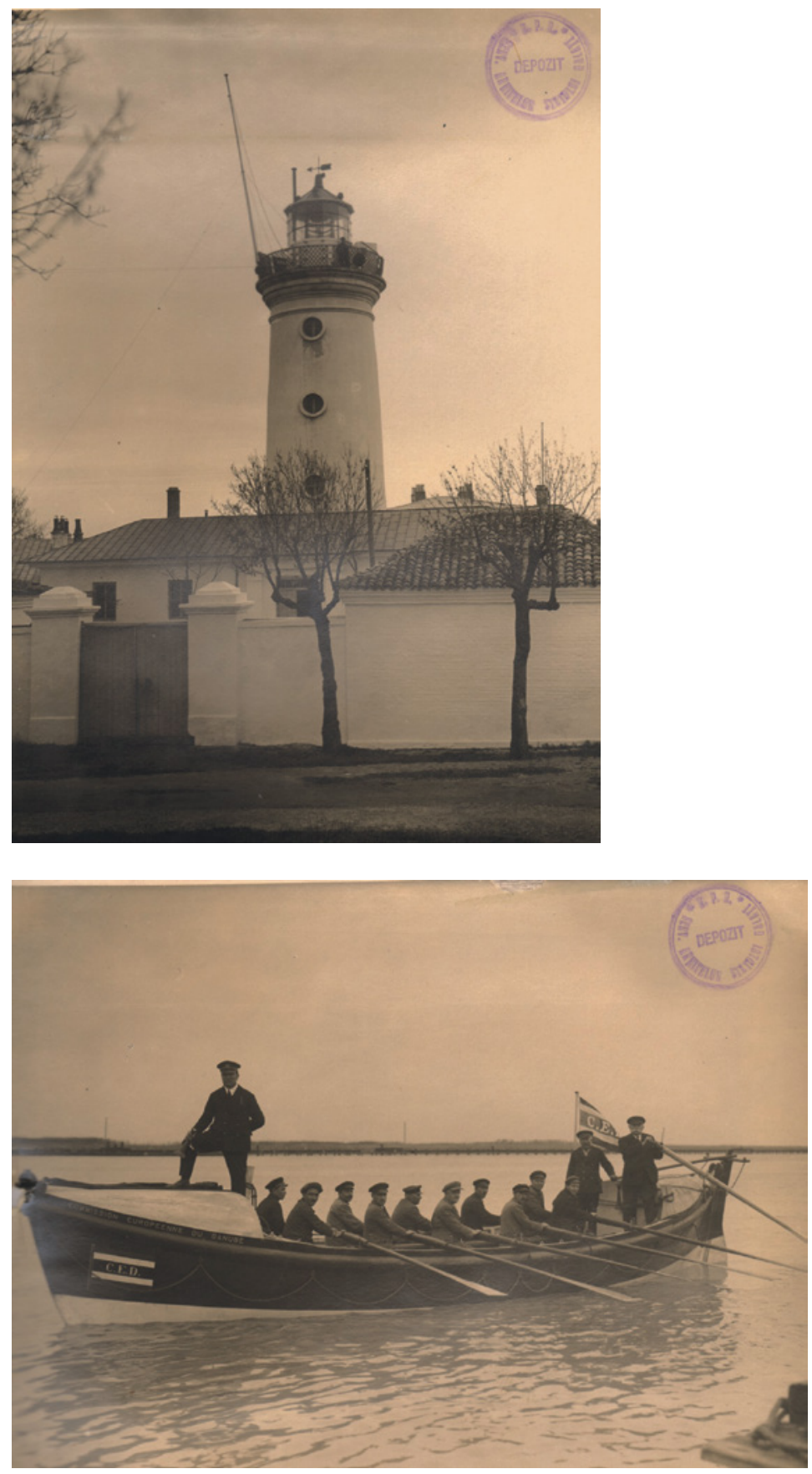

FIGURES 13-14 The lighthouse of Sulina and the Rescue Service (1930) SOURCE: THE NATIONAL ARCHIVES OF ROMANIA, GALAȚI BRANCH 
Service and created, under the direction of an instructor, a special lifesaving unit which was always ready for rescue missions. A year later a medal was established for meritorious acts of lifesaving. ${ }^{86}$

\section{A Statistical Perspective on Shipping Security}

The combined effect of the Commission's hydraulic and normative activity of rulemaking was visible in the decrease of the number of accidents in the Maritime Danube. From 1861, the organisation kept precise records of accidents within its jurisdiction, and after 1867 published detailed reports on their causes. Each year the Commission recorded a large number of shipping 'accidents', which included collision, grounding, foundering and the like. Those that resulted in the permanent loss of a ship are referred to as 'shipwrecks'. As Table 6 below shows, during the period $1855^{-1860}$ available statistics report an incredible total of 120 shipwrecks: 62 in the Sulina roadstead, 42 on the coast of the delta, 3 in the port of Sulina and 13 on the Danube. During the next halfcentury 'only' 124 wrecks were recorded: 50 (40.3 per cent) on the coast of the Danube Delta, 37 (29.8 per cent) in the Sulina roadstead, 6 (4.8 per cent) in the port of Sulina and 31 (25 per cent) in the Maritime Danube. Chronologically, 71 (57.2 per cent) took place in the 186 os and 30 (24.2 per cent) in the next decade, whereas only 23 ( 18.6 per cent) occurred in the following 34 years.

TABLE 6 Shipwrecks on the Maritime Danube by place of occurrence, 1861-1914

\begin{tabular}{lcccccc}
\hline Period & River & $\begin{array}{l}\text { Port of } \\
\text { Sulina }\end{array}$ & $\begin{array}{l}\text { Sulina } \\
\text { roadstead }\end{array}$ & $\begin{array}{l}\text { Coast of } \\
\text { the Delta }\end{array}$ & Total & $\begin{array}{l}\text { Annual } \\
\text { average }\end{array}$ \\
\hline $1855^{-1860}$ & 13 & 3 & 62 & 42 & 120 & 20 \\
$1861-1870$ & 17 & 4 & 25 & 25 & 71 & 7.1 \\
$1871-1880$ & 8 & 1 & 5 & 16 & 30 & 3.0 \\
$1881-1890$ & 5 & 1 & 4 & 6 & 16 & 1.6 \\
$1891-1900$ & 1 & - & - & 3 & 4 & 0.4 \\
$1901-1910$ & - & - & 1 & - & 1 & 0.2 \\
$1911-1914$ & - & - & 2 & - & 2 & 0.5 \\
Total 1861-1914 & 31 & 6 & 37 & 50 & 124 & - \\
\hline
\end{tabular}

SOURCE: LA COMMISSION EUROPÉENNE DU DANUBE ET SON CEUVRE DE 1856 À 1931 (PARIS 1931), 501 (ANNEXE XXI) 
Besides the improvements brought about by the legislative and technical activity of the Commission, another factor which contributed to the decline in the number of accidents was the quality of the vessels navigating in the Danube. The transition from sail to steam after the 1870 s provided increased security against the rapidly changing weather conditions of the Black Sea. However, the larger vessels that began to arrive on the Danube did not ease the congestion. As the large steamers awaited their cargoes in the roadstead, thus avoiding the river's shallow waters, grain was carried to Sulina by a flotilla of lighters and tugs, which made the central branch of the river a very busy transport corridor and increased the opportunities for accidents (Chapter 9). ${ }^{87}$ Thus, besides the sinking of seagoing vessels, the Commission also recorded 46 shipwrecks of lighters. Most of the accidents took place after collisions with larger steamers, which made it necessary to establish special regulations for their operation, as presented above.

Accidents on the Black Sea coast were also due to the usual factors that are responsible for disasters in maritime navigation. In more than half the cases bad weather, thick fog and strong currents were to blame. The sudden storms which plagued the area were especially dangerous for sailing vessels, but there were also many instances in which vessels were damaged by navigational errors, fire, or design and equipment failures. For example, in December 1878 the Greek ship Bethlehem, bound for Sulina from Istanbul, sank south of Sulina due to fog and violent northeasterly winds. Eight members of the crew were lost, and only three made it ashore alive. In March 1879, the Russian lotka Sveti Haralambi, with 70 tons of cargo, was driven onto the coast by a violent northeast wind, causing the death of two seamen and the complete loss of the vessel. The Russian schooner Svistoi Georghi was caught by a storm in September 1881 while lying at anchor. Its chains were broken by the combined force of the wind and the violent sea; two of the crew managed to save themselves, but the master and two other seafarers perished. A violent storm was recorded in October 1882, when no fewer than four vessels were shipwrecked. Another tragic case was the British steamer Red Star, which was loading in the Sulina roadstead when a gale struck. Three of the crew drowned and the ship, with a cargo of barley, sank the same night. ${ }^{88}$

All these climatic conditions were exacerbated by the fact that the coastal waters near the Danube mouths were shallow due to alluvial deposits borne by the river. At the same time, the northeasterly winds pushed the ships directly

\footnotetext{
87 See the detailed statistics in Ardeleanu, Evoluția intereselor economice și politice britanice la gurile Dunării (1829-1914) (Brăila 2008), 311-347.

88 PECD, Statistique de la navigation à l'embouchure du Danube, 1878, 1879, 1881 and 1882. "État no. 9: Naufrages survenus aux embouchure et dans le Bas-Danube."
} 
towards the coast, where few harbours offered shelter. Fog, poor visibility and darkness increased the problems for navigators. Human error or unfamiliarity with the region was another important cause of accidents. In February 1871, the Italian barque Alexandro Secondo suffered severe damage at the Sulina mouth, which the captain tried to enter without a local pilot. Refloated and anchored ten miles south of Sulina, it was abandoned by the crew who felt it was in imminent danger of sinking. Their attempt led to another tragedy, as four men drowned after trying to escape by landing on the thin ice. ${ }^{89}$

Collisions were another frequent cause of accidents. In June 1868, the Italian brig Allesandrina sank in the port of Sulina after colliding with a British steamer. In December 1878, an Ottoman ship carrying ammunition sank in the port of Sulina after colliding with the Austro-Hungarian steamer Thetis, while in September 1896 the British steamer Kylemore was struck about four miles from the mouth by the British steamer March which was inbound from Port Said. As a result, the Kylemore sank and a passenger drowned. ${ }^{90}$

Fires, caused by human error or accidents, were another significant factor leading to shipwrecks. However, in about 75 per cent of the known cases of shipwrecks on the Maritime Danube, the accidents occurred as a result of collisions between two ships, between a vessel and the riverbanks or with sunken ships. In August 1896, one of the Commission's barges sank at the forty-eighth mile following a collision with the British steamer Trevanion; two crew members died and the barge could not be refloated. In several instances, vessels navigating in the Maritime Danube collided with the banks, spurs or sunken ships. The British steamer Castanos, carrying about 1,970 tons of maize, sank at the Ismail Fork in June 1893 after colliding with the remains of the wreck of the Carlo. After this incident, the Commission initiated an ambitious (and dangerous) plan to remove the numerous wrecks, mostly by using gunpowder and dynamite. ${ }^{91}$

The remarkable activity of the Commission in terms of hydraulic and normative works is clearly visible in the number of shipwrecks recorded at the Maritime Danube. From an annual average of twenty shipwrecks in the late 1850s, the number decreased to only three shipwrecks between 1901 and 1915, all in the Sulina roadstead. The Commission could boast that shipping along the Maritime Danube was completely safe.

$89 \quad$ Ibid., 1867 and 1871.

$90 \quad$ Ibid., 1868,1878 and 1896 .

91 Ibid., 1876, 1880, 1893, 1896, 1901 and 1914. 


\section{$11 \quad$ Conclusions}

Two conclusions are self-evident at the end of this chapter. The first refers to the gradual professionalisation of the Commission staff, an efficient transnational bureaucracy that updated its practices simultaneously with the consolidation of the organisation's status. Some of the most important values promoted in the organisation were loyalty and continuity, both very well rewarded financially. Given the uncertainty related to the Commission's lifespan and to the difficult living conditions in the Danube Delta, as well as the need for qualified personnel that were not easily available in southeastern Europe, the Commission's top management, both at the level of commissioners and heads of services, designed procedures that allowed the organisation to simply recruit and promote staff, which at the same time nourished the employees' corporate identity.

The second refers to the Commission's drive towards standardisation and simplification in terms of rules, norms and procedures. The organisation drafted hundreds of regulations and directives, much like current European bureaucracy, turning the Maritime Danube into an experimental laboratory of international administration.

The results of this security regime are clear when looking at Danubian navigation. The Commission recorded detailed information on shipping accidents. A quantitative analysis of shipwrecks shows how much safer navigation came to be in the early twentieth century as compared to the early post-Crimean War years. Hydraulic works account for a larger portion of this increased safety, but the Commission's normative work is as important. Regulations and enforcing institutions, navigational aids and a functional juridical system all contributed to turning shipping into a more secure business. With the organisation of pilotage and lighterage, the Commission invested in an additional dimension that aimed to attract entrepreneurs to the Maritime Danube: a friendlier economic environment, with more honest and remunerative services. 